\title{
Pelatihan Pemasaran Produk Olahan Kelapa Berbasis Ekonomi Digital pada UMKM Andana VCO Kabupaten Lombok Utara
}

\author{
Dewa Nyoman Adi Paramartha ${ }^{1^{*}}$, Zainuri $^{2}$, Yeni Sulastri ${ }^{3}$, Rucitra Widyasari ${ }^{4}$, Rini Nofrida ${ }^{5}$ \\ 1,2,3,4,5 Fakultas Teknologi Pangan dan Agroindustri, Universitas Mataram, Mataram \\ *dewanyoman.adip@unram.ac.id
}

\begin{abstract}
Abstrak
Pandemi Covid-19 sejak 2020 telah banyak merubah perekonomian, yang paling terdampak adalah pengusaha kecil dan menengah, untuk bisa bertahan UMKM harus mampu beradaptasi baik konsumen maupun cara pemasaran dan penjualan. Di satu sisi era MEA saat ini mengharuskan UMKM untuk dapat berubah dan beradaptasi lebih cepat sehingga mampu bersaing di pasaran. Salah satunya adalah dengan penerapan ekonomi digital yang mampu bersinergi dengan ekonomi kreatif. Pengabdian ini meliputi 1) memberikan pemahaman tentang berjualan produk dengan penerapan ekonomi digital dan 2) melatih pelaku bisnis berbasis kelapa untuk memulai berjualan produk dengan penerapan ekonomi digital. Pengabdian ini telah dilaksanakan pada tanggal 26 Juli 2021, yang bertempat di Dusun Karang Kates, Kecamatan Gondang-Gangga, Kabupaten Lombok Utara dengan sasaran mitra yaitu UKM Andana VCO. Pelaksanaan kegiatan pengabdian ini menerapkan metode pelatihan yaitu pelatihan UMKM go digital dan pelatihan pemasaran digital. Untuk jangka panjang, diharapkan bahwa pengetahuan dan keterampilan yang didapatkan dapat memberikan kemajuan bagi pengelolaan manajemen usaha.
\end{abstract}

Kata kunci: ekonomi digital, kelapa, pemasaran digital

\section{Pendahuluan}

Kelapa merupakan salah satu komoditas hasil pertanian yang telah banyak dimanfaatkan dalam potensi ekonomi kreatif bagi industri kelapa. Salah satu industri kelapa yang beroperasi dalam ekonomi kreatif di Lombok Utara, Nusa Tenggara Barat adalah mitra Andana VCO. Mitra Andana VCO telah beroperasi sejak tahun 2018 berlokasi di Dusun Karang Kates, Kecamatan Gondang-Gangga, Kabupaten Lombok Utara. Produk yang telah dihasilkan oleh mitra dari penerapan ekonomi kreatif yaitu virgin coconut oil (VCO), desiccated coconut dari limbah VCO dan coconut chip. Produk tersebut telah dijual secara offline yang dijual didepan rumah produksi maupun online menggunakan Facebook dan Whatsapp, namun hasil yang didapatkan belum memenuhi target penjualan. Hal ini disebabkan minimnya pengetahuan teknologi dan manajemen usaha. Salah satu solusi yang dapat dilakukan untuk memperbaiki pengelolaan usaha yaitu melalui penjualan secara ekonomi digital.

Ekonomi digital ini dilakukan melalui media daring yang dapat membantu mitra untuk menginformasikan produk ke konsumen dalam jangkauan lebih luas secara online agar konsumen mengetahui produk yang dijual oleh mitra dan menjajakannya di marketplace yang saat ini di masa pandemi sedang trendnya online shop. Produk yang dibuat oleh mitra bisa dilakukan penjualan di marketplace yang telah tersedia secara gratis contohnya Shopee dan 
Tokopedia. Kedua marketplace tersebut telah memiliki banyak pengguna akun platform belanja digital yang menggunakannya. Menurut Sirclo (2020), pertumbuhan pangsa pasar ekonomi digital di Indonesia tiap tahunnya semakin meningkat dengan adanya peralihan sistem belanja di masa pandemi melalui online. Pengguna internet di Indonesia sebesar $88 \%$ telah membeli produk secara online. Jumlah pengunjung Shopee mencapai 96,5 juta sedangkan Tokopedia sebesar 84,9 juta. Tentu hal tersebut menjadi sebuah peluang yang menguntungkan dalam penjualan produk secara online bagi mitra usaha.

Peluang dalam ekonomi digital diperlukan juga peran strategi pemasaran online. Lingkup persaingan ekonomi digital sangat ramai pesaing, untuk itu diperlukan strategi pemasaran yang efektif menarik minat konsumen membeli produk. Pemasaran online adalah metode mengintegrasikan media baru pada penerapan strategi pemasaran. Salah satu media yang adaptif dalam pemasaran online yaitu beriklan di Facebook. Facebook business manager merupakan media iklan fungsional dalam mengkampanyekan suatu produk. Beriklan di Facebook adalah salah satu pilihan terbaik dalam pemasaran Internet. Tidak ada fitur sosial media lain yang dapat membuat pengiklan dapat menargetkan secara spesifik penggunanya. Publik juga dapat mengiklan dengan biaya lebih sedikit daripada biaya iklan offline atau cetak dengan penargetan yang sama. Meski begitu, beriklan menggunakan Facebook tidaklah semudah yang diharapkan. Iklan Facebook bekerja secara berbeda dari iklan banner. Pengguna merespon iklan online secara berbeda tergantung demografi dan norma sosial, beberapa iklan bekerja lebih baik dari lainnya. Dalam pemasaran online berperan juga komunikasi pemasaran dalam beriklan di Facebook. Komunikasi pemasaran yang jelas, kreatif dan efektif bisa menarik minat konsumen untuk membeli produk. Kesuksesan beriklan di Facebook dibutuhkan pemantauan yang cekatan, eksperimen, kesabaran dan kreatifitas (Treadway dan Smith, 2010).

Berdasarkan uraian tersebut, perkembangan teknologi membuat kondisi semakin dinamis dan menuntut perusahaan untuk bergerak mengikuti kemajuan yang ada jika tidak mau tertinggal atau ingin bersaing dengan kompetitor usaha serupa. Terkait dengan prinsip ekonomi dimana seseorang selalu menginginkan keuntungan sebanyak-banyaknya dan selalu bertambah dengan tidak merugi juga secara biaya operasional yang dikeluarkan. Oleh karena itu di era digital, banyak usaha yang berkembang di masyarakat mulai beralih dan memanfaatkan media online untuk memasarkan produk bisnisnya. Media online merupakan media massa yang interaktif dibandingkan media konvensional (Kovach dan Tom, 2006).

Industri yang telah menerapkan ekonomi kreatif juga harus menerapkan ekonomi digital supaya tidak tertinggal laju bisnis dengan kompetitor dan mengoptimalkan kinerja penjualan produk. Saat ini, baru sebanyak 8,3 juta dari 56 juta pelaku UMKM secara nasional yang memanfaatkan teknologi digital, padahal ini lebih diperlukan saat pandemi Covid-19. Beberapa usaha yang tidak mengalami penurunan pendapatan adalah mereka yang menggunakan sarana penjualan online untuk usahanya. Maka, marketplace untuk memfasilitasi UMKM menjadi 
semakin diperlukan (Moegiarso, 2020). Untuk itu telah dilakukannya pelatihan berjualan produk berbasis kelapa dengan penerapan ekonomi digital di industri Andana VCO.

\section{Metode Pelaksanaan}

Rancangan kegiatan pengabdian yang telah dilaksanakan adalah dengan menerapkan metode pelatihan wirausaha berbasis kelapa melalui ekonomi digital, metode ini meliputi: (1) pelatihan UMKM Go Digital. Pelatihan UMKM Go Digital merupakan suatu cara melatih pemilik UKM Andana VCO agar siap praktik dalam mengoptimalkan pemasaran melalui platform belanja online atau kanal marketing. Kegiatan pelatihan ini terjadi proses penyampaian materi, simulasi, diskusi dan praktik serta evaluasi tentang pengenalan kanal marketing dan platform desain grafis yang dilaksanakan dalam penerapan ekonomi digital. Pelatihan ini bertujuan untuk menambah wawasan dan keterampilan mitra dalam menggunakan teknologi yang dapat membantu usahanya; dan (2) pelatihan pemasaran digital. Pelatihan pemasaran digital merupakan pelatihan dalam merencanakan pemasaran digital. Kegiatan pelatihan ini terjadi proses penyampaian materi dan diskusi tentang pengenalan pemasaran digital. Pelatihan ini bertujuan untuk memberikan pengetahuan dan kemampuan bagi mitra agar dapat mempromosikan sebuah produk dengan menggunakan media digital.

\section{Hasil Kegiatan dan Pembahasan}

Kegiatan program pengabdian masyarakat telah dilaksanakan pada tanggal 26 Juli 2021 di UKM Andana VCO yang berlokasi di Dusun Karang Kates, Kecamatan Gondang-Gangga, Kabupaten Lombok Utara. Pengabdian ini dilaksanakan sebagai upaya pelatihan melalui pembelajaran pada UKM Andana VCO agar menambah pengetahuan dan kemampuan tentang berjualan produk di era ekonomi digital. Adapun cakupan pelatihan yang telah dilakukan, sebagai berikut:

\section{a. Pelatihan UMKM Go Digital}

Pelatihan ini diawali dengan memberikan pengetahuan kepada pemilik UKM Andana VCO tentang pentingnya berjualan produk di era ekonomi digital. Adapun uraian pelatihan yang diberikan, antara lain:

1. Penyampaian Materi, Simulasi dan Diskusi Tentang Pengenalan Kanal Marketing di Era Ekonomi Digital

Penyampaian materi dimulai dari pentingnya beralih berjualan produk secara ekonomi digital. Ekonomi digital merupakan transformasi usaha dengan memanfaatkan teknologi digital. Seiring masih dalam kasus Covid-19 mulai timbul perubahan perilaku konsumen yang menjadi lebih senang bertransaksi secara online dan sejalan dengan anjuran tetap menerapkan protokol kesehatan. Dari hal tersebut tentunya harus juga mengikuti 
perubahan yang ada dalam memanfaatkan peluang menggunakan teknologi digital untuk dapat bertahan, mengembalikan pemulihan ekonomi secara bertahap dan mendorong pertumbuhan ekonomi kreatif. Menurut Niken (2020), digitalisasi ekonomi memiliki keuntungan yaitu: (1) aman dalam bertransaksi secara online dan terekap dengan otomatis data-data penjualan; (2) mudah melakukan penjualan secara online melalui kanal marketing yang telah tersedia seperti Instagram bisnis, beriklan Facebook dan Shopee; (3) cepat dalam bertransaksi jual beli sehingga terhindar dari mengantri dan tetap menjaga jarak sesuai anjuran protokol kesehatan; dan (4) Jangkauan target pasar menjadi lebih luas.

Aktivitas ekonomi digital yang dapat dilakukan dalam jual beli produk atau jasa yaitu dengan menyediakan kanal marketing. Kanal marketing merupakan saluran pemasaran produk atau jasa yang dilakukan secara online dengan menggunakan media sosial, layanan belanja online maupun pemasaran secara digital lainnya. Selama pemberian materi, pemateri juga telah memberikan simulasi atau tutorial tentang penggunaan kanal marketing. Pemateri memberikan 3 contoh penggunaan kanal marketing yang biasanya digunakan oleh para pelaku bisnis secara digital. Contohnya yaitu: (1) Instagram bisnis (media sosial), merupakan media penyedia layanan sosial secara online yang dapat dijadikan sebagai tempat mempromosikan produk atau jasa. Cara untuk memaksimalkan penggunaan Instagram bisnis untuk penjualan produk adalah (1) menentukan target audiens; (2) mengoptimasi profil instagram bisnis; (3) menjadwalkan posting; (4) membuat konten yang menarik; (5) membuat Instagram stories; (6) Instagram Ads dan (7) melakukan analisa performa akun Instagram bisnis (Sekar, 2020); (2) beriklan Facebook (layanan iklan secara online), Facebook telah memiliki banyak pengguna media sosial sehingga Facebook menghadirkan layanan iklan yang dapat membantu pelaku bisnis untuk menjangkau lebih banyak target pemasaran; dan (3) Shopee (platform belanja online) Shopee memiliki banyak fitur pendukung dalam bertransaksi digital secara cepat, aman dan adanya kemudahan layanan iklan berbayar untuk menjangkau lebih banyak target pasar serta didukung dengan tersedianya fitur pengiriman dalam memudahkan distribusi produk seperti JNE, J\&T, SiCepat, Anteraja, ID Express, Pos Kilat, Ninja Xpress, GrabExpress dan GoSend. Penyampaian materi, simulasi dan diskusi tentang penggunaan kanal marketing di era ekonomi digital dapat dilihat pada Gambar 1. Hasil kanal marketing yang dibuat dengan bantuan arahan dari pemateri dapat diakses pada https://www.instagram.com/andana.vco/. 


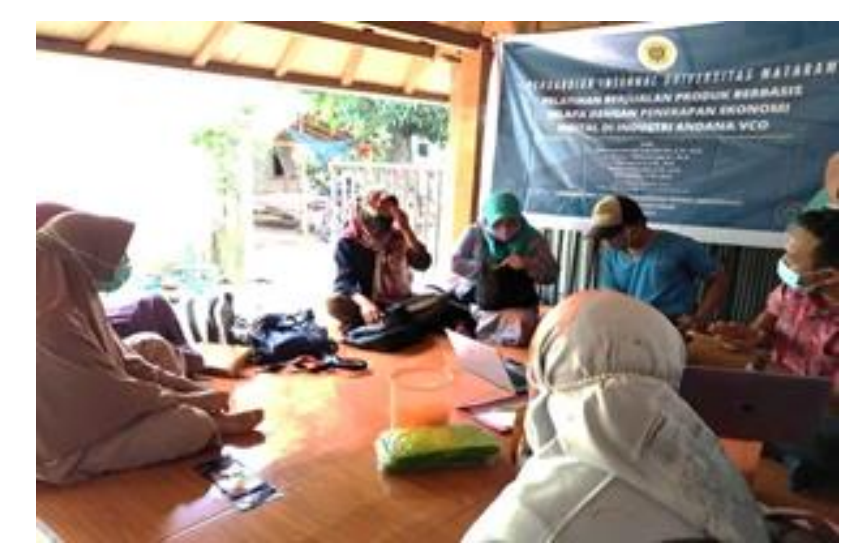

Gambar 1. Kegiatan Penyampaian Materi, Simulasi dan Diskusi

Sumber: Dokumentasi Tim Pengabdian FATEPA Unram, 2021

2. Penyampaian Materi, Simulasi dan Diskusi Tentang Pengenalan Platform Desain Grafis

Kegiatan ini dilakukan dengan memberikan pengetahuan dan kemampuan bidang desain grafis melalui penyampaian materi dan simulasi. Desain grafis merupakan elemen utama atau hal dasar dalam menciptakan komunikasi visual secara digital yang memanfaatkan gambar sebagai perantara pesan atau informasi kepada komunikan. Salah satu platform desain grafis yang dapat digunakan untuk pemula yaitu canva. Canva merupakan platform pembuat desain grafis yang sangat mudah untuk digunakan pada smartphone dan komputer pribadi. Canva berisi berbagai contoh grafis media sosial, logo, label produk, presentasi, dokumen dan konten visual lainnya yang dapat digunakan langsung untuk kebutuhan kegiatan media digital. Canva hadir dalam dua versi yaitu versi berbayar atau Canva Pro yang dapat menikmati berbagai fitur premiumnya dengan harga perbulannya $\mathrm{Rp} 95.000$ dan pertahunnya Rp 769.000 untuk maksimal 5 orang dalam satu tim dan versi Canva gratis yang hanya sedikit dapat menikmati beberapa fitur gratis. Selama pemberian materi, pemateri juga memberikan simulasi atau tutorial tentang cara penggunaan Canva dalam pembuatan konten penjualan produk yang akan dipostingkan ke Instagram, Facebook, Iklan di Facebook dan marketplace. Dalam menggunakan Canva hal-hal yang dilakukan adalah (1) mendaftar akun Canva menggunakan akun Google, Facebook atau buat email Canva; (2) memilih ukuran konten yang akan dipostingkan ke media penjualan digital; (3) membuat desain karya sendiri atau dapat memilih desain yang telah ada di Canva; (4) mengedit dan menambahkan teks, gambar atau menganimasikan desain konten yang akan dibuat; dan (5) mengunduh atau membagikan desain yang telah selesai dibuat dengan disesuaikannya format konten yang dibutuhkan. Kegiatan diakhiri dengan diskusi dan menguji kembali ingatan pemilik usaha tentang penguasaan materi dan simulasi penggunaan platform desain grafis. Antusiasme pemilik usaha dalam kegiatan ini sangat tinggi untuk menambah pengetahuan dan kemampuan yang ditandai dengan keaktifan dalam tanya jawab yang telah dilakukan. Penyampaian materi, simulasi dan diskusi tentang penggunaan platform desain grafis dapat dilihat pada Gambar 2. 


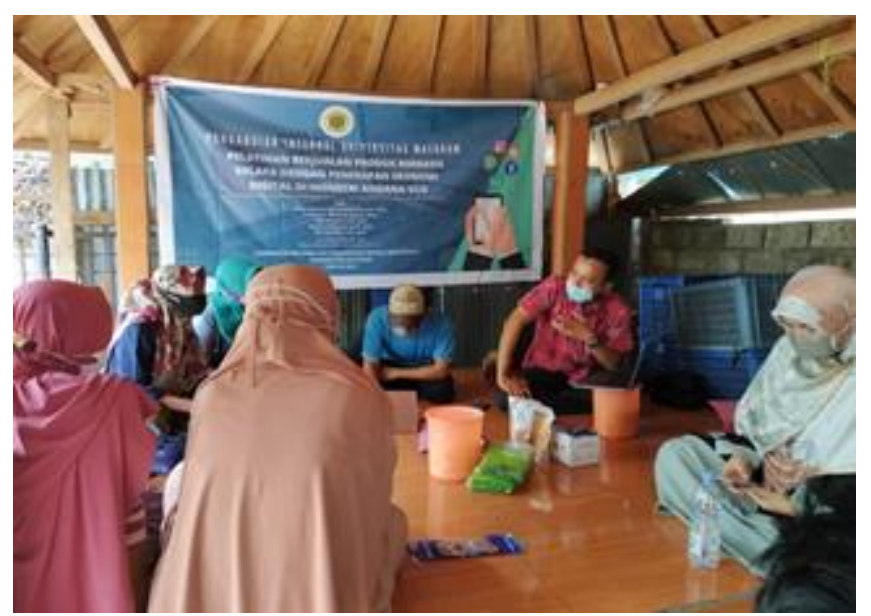

Gambar 2. Penyampaian Materi, Simulasi dan Diskusi Tentang Pengenalan Platform Desain Grafis Sumber: Dokumentasi Tim Pengabdian FATEPA Unram, 2021

3. Praktik dan Evaluasi Pelatihan

Kegiatan ini dimulai dari menanyakan keinginan dan ketertarikan pemilik UKM Andana VCO dari hasil penyampaian materi dan simulasi yang sudah diberikan oleh pemateri. Pemilik UKM Andana VCO menyampaikan keinginan dan ketertarikan utamanya untuk memperbarui tampilan label produk VCO dengan menggunakan platform desain grafis berupa Canva. Dari hasil uji coba yang dilakukan, pemilik UKM Andana VCO sudah bisa melakukan pembuatan label menggunakan Canva yang terdesain sangat menarik. Kegiatan praktik dan evaluasi pelatihan yang dilakukan dapat dilihat pada Gambar 3. Label produk sebelum pembaruan dapat dilihat pada Gambar 4 dan hasil pembaruan label produk VCO menggunakan Canva dapat dilihat pada Gambar 5.

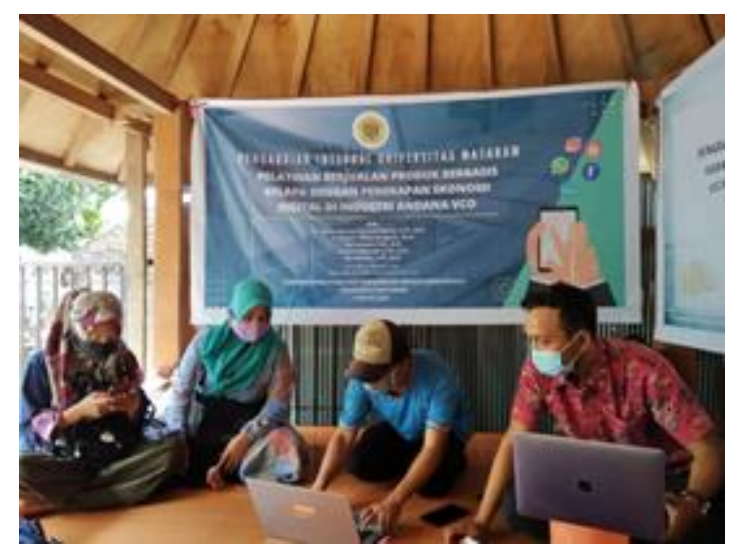

Gambar 3. Kegiatan Praktik dan Evaluasi Pelatihan

Sumber : Dokumentasi Tim Pengabdian FATEPA Unram, 2021 


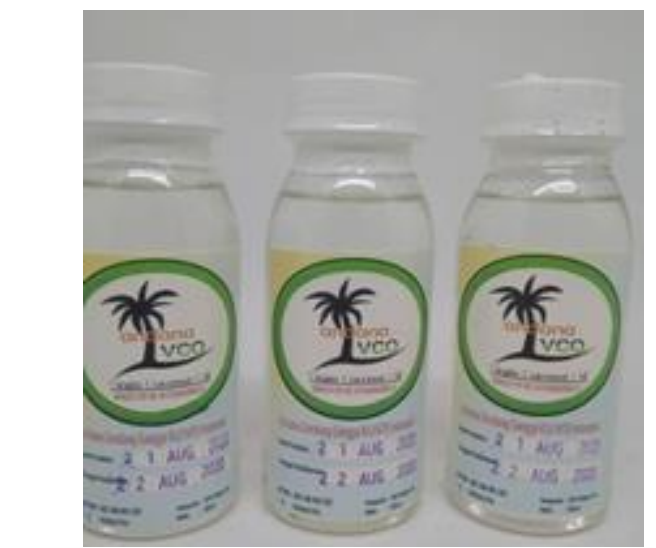

Gambar 4. Label Produk Sebelum Pembaruan

Sumber : Instagram Andana VCO, 2019

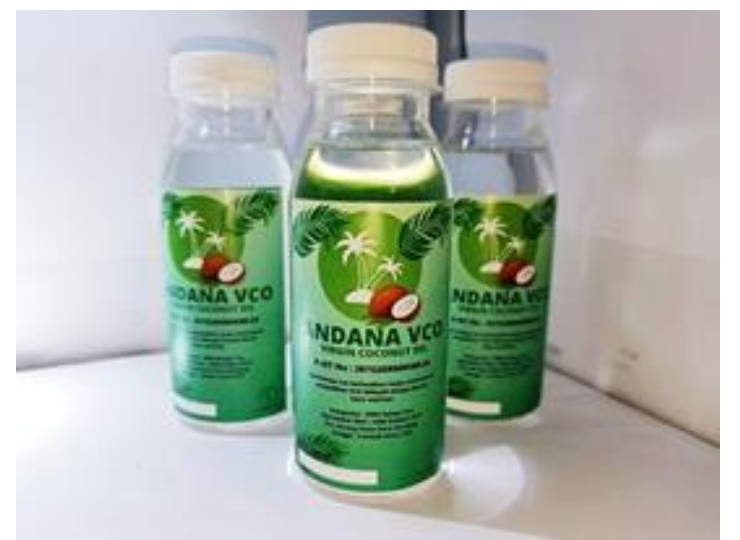

Gambar 5. Hasil Perbaruan Label Produk milik Industri Andana VCO Menggunakan Canva Sumber : Dokumentasi Tim Pengabdian FATEPA

Unram, 2021

\section{b. Pelatihan Pemasaran Digital}

Pelatihan pemasaran digital yang dilakukan yaitu dengan memberikan pemaparan materi dan diskusi selama pelatihan berlangsung. Penyampaian materi ini dimulai dengan memberikan pemahaman kepada pemilik UKM Andana VCO mengenai pemasaran digital. Menurut Priharto (2020), pemasaran digital adalah pemasaran produk atau layanan dengan menggunakan teknologi digital melalui internet, media sosial, telepon seluler, atau media digital lainnya. Tujuan pemasaran digital yaitu untuk dapat menarik minat konsumen secara luas dan cepat. Seiring berjalannya waktu, pertumbuhan pengguna teknologi digital semakin pesat hal ini terlihat dari tren penggunaan media sosial seperti Facebook dan Instagram serta tren belanja online seperti menggunakan Shopee dan Tokopedia. Sehingga dari tren tersebut timbul layanan promosi atau iklan secara digital yang memudahkan pelaku bisnis untuk menjangkau lebih banyak konsumen dengan menggunakan iklan Facebook dan iklan Google. Menurut Witdya (2020), kelebihan yang didapatkan dalam pemasaran digital yaitu kecepatan penyebaran, kemudahan evaluasi, jangkauan lebih luas, murah dan efektif serta membangun nama brand dengan baik. Jenis - jenis pemasaran digital yang digunakan oleh para pelaku bisnis yaitu website, sosial media dan promosi atau iklan melalui internet dengan berbayar.

Membangun pemasaran digital diperlukan juga pengoptimalan melalui strategi pemasaran. Memiliki strategi pemasaran sama pentingnya dengan memiliki rencana untuk mencapai tujuan dipasarkannya sebuah brand. Hal yang diperlukan untuk mencapai tujuan atau target pasar yaitu bauran pemasaran yang terdiri dari 4P (product, price, place dan promotion). Selain bauran pemasaran diperlukan juga penyiapan content marketing. Menurut Dewanti dan Heni (2018), content marketing adalah strategi pemasaran dengan cara menghasilkan konten yang bertujuan untuk memberi informasi kepada target (konsumen) yang bersifat persuasi, atas produk yang dipasarkan. Content marketing diperlukan dalam konsep kanal marketing agar dapat menciptakan interaksi antara penjual dan pembeli secara online. Content marketing akan 
membangun sebuah pondasi kepercayaan bagi konsumen terhadap informasi yang disampaikan jelas dan berguna dalam berjualan produk. Jadi, hal yang perlu diperhatikan dalam content marketing untuk jangka panjang adalah mengembangkan customer engagement (interaksi antara penjual dan pembeli dari beberapa kanal marketing yang terhubung akses internet atau online) dan trust (kepercayaan pelanggan terhadap layanan dan produk yang dijual). Kegiatan diakhiri dengan diskusi dengan cara menguji kembali ingatan pemilik usaha tentang pemasaran digital dan senantiasa aktif selama sesi tanya jawab berlangsung. Kegiatan pelatihan pemasaran digital yang dilakukan dapat dilihat pada Gambar 6.

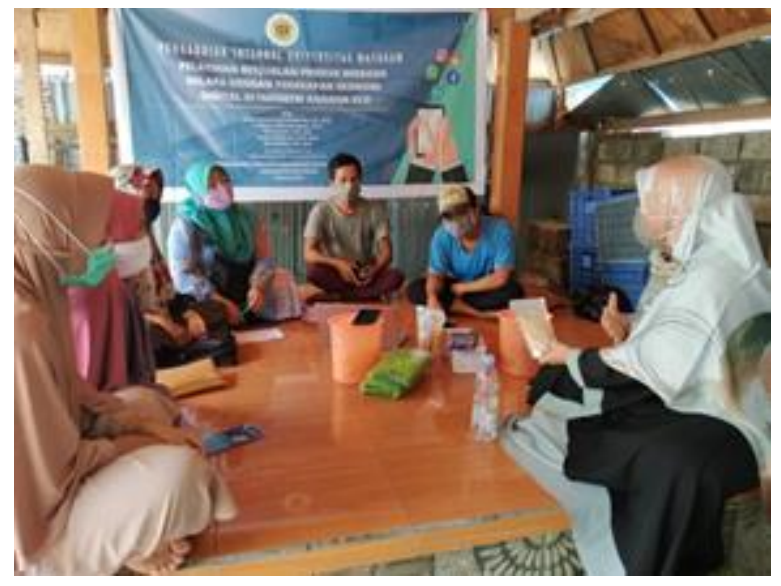

Gambar 6. Pelatihan Pemasaran Digital

Sumber : Dokumentasi Tim Pengabdian FATEPA Unram, 2021

\section{Simpulan dan Saran}

Kegiatan pengabdian untuk pelatihan berjualan produk berbasis kelapa dengan penerapan ekonomi digital yang telah dilakukan berjalan dengan lancar. Pemilik UKM Andana VCO sangat antusias dalam mengikuti kegiatan dan bersemangat untuk menerapkan dalam kegiatan usahanya. Kegiatan ini perlu dilakukan karena dibutuhkan oleh pemilik usaha sebagai bentuk pemulihan ekonomi dengan menggunakan penerapan ekonomi digital. Dalam jangka panjang, pengetahuan yang diberikan dalam kegiatan pelatihan berjualan produk berbasis kelapa dengan penerapan ekonomi digital ini diharapkan mampu mendongkrak penjualan produk UKM Andana VCO.

Kegiatan pengabdian pelatihan berjualan produk berbasis kelapa dengan penerapan ekonomi digital semacam ini perlu dilakukan di industri lainnya yang masih kekurangan pengetahuan dan kemampuan beradaptasi dengan teknologi digital. Secara khusus pemerintah, melalui dinas-dinas terkait, diharapkan lebih banyak berperan dalam kaitan ini, untuk bersinergi dalam pertumbuhan ekonomi digital bagi para pelaku bisnis lainnya.

\section{Ucapan Terima Kasih}

JCommdev Vol 2, No. 3, 2021, hlm. 85 - 93 
Diucapkan terima kasih kepada tim Pengabdian Fakultas Teknologi Pangan dan Agroindustri Universitas Mataram dan UKM Andana VCO di Dusun Karang Kates, Kecamatan GanggaGondang, Kabupaten Lombok Utara. Kegiatan pengabdian ini dilaksanakan menggunakan dana PNBP UNRAM tahun 2021.

\section{Daftar Pustaka}

Dewanti, P. dan Henni, G. Pengaruh Content Marketing Terhadap Pembentukan Brand Awareness pada Kalbis Institute. Jurnal Media Kom, 8(2), 45-47. Retrieved from https://publikasi.mercubuana.ac.id/index.php/mediakom/article/view/3915

Instagram Andana VCO. (ed.) 2019. Foto Produk UKM Andana VCO. Retrieved September 28, 2021 from https://www.instagram.com/andanavco/

Kovach, B. dan Tom, R. (2006). Sembilan Elemen Jurnalisme. Jakarta : Yayasan Pantau.

Moegiarso, S. (ed.). (2020). Sediakan Pelatihan dan Sertifikasi Halal, Pemerintah Dorong Industri Halal Nasional Mendunia. Retrieved Februari 26, 2021 from https://ekon.go.id/publikasi/detail/586/ sediakan-pelatihan-dansertifikasi-halal-pemerintah-dorong-industri-halal-nasional-mendunia

Niken, G. (ed.). (2020). Ekonomi Digital : Pengertian dan Contoh - Contohnya. Retrieved Februari 25, 2021 from https://webcache.googleusercontent.com/search?q=cache:w7b_T439LjgJ:https://ajaib.co.id/ekonomi-digitalpengertian-dan-contoh-contohnya/+\&cd=1\&hl=id\&ct=clnk\&gl=id

Priharto, S. (ed.) (2020). Pengertian Pemasaran Digital dan Bermacam Strateginya. Retrieved Februari 26, 2021 from https://accurate.id/marketing-manajemen/pengertian-pemasaran-digital-dan-strateginya/

Sekar, N. (ed.). (2020). 7 Cara Memaksimalkan Instagram Bisnis untuk Mendongkrak Penjualan. Retrieved Februari 26, 2021 from https://www.niagahoster.co.id/blog/instagram-bisnis/

Sirclo. 2020. Jumlah Pengguna E-Commerce Indonesia di Tahun 2020 Meningkat Pesat. Retrieved Februari 24, 2021 from https://www.sirclo.com/jumlah-pengguna-e-commerce-indonesia-di-tahun-2020-meningkat-pesat

Treadway, C. \& Smith, M. (2010). Facebook Marketing an Hour a Day. Indianapolis. Indiana : Wiley Publishing, Inc.

Witdya, P. (ed.). (2020). Pengertian, Kelebihan, Jenis dan Strategi Digital Marketing. Retrieved Maret 21, 2021 from https://www.jurnal.id/id/blog/mengenal-digital-marketing-konsep-dan-penerapannya/

JCommdev Vol 2, No. 3, 2021, hlm. 85 - 93 